ROCZNIKI NAUK PRAWNYCH

Tom XXX, numer $2-2020$

DOI: https://doi.org/10.18290/rnp20302-8

\title{
PIOTR TELUSIEWICZ
}

\section{PRZESŁANKI UZYSKANIA RODZICIELSKIEGO ŚWIADCZENIA UZUPEŁNIAJĄCEGO}

\section{WSTĘP}

W dniu 1 marca 2019 r. weszła w życie ustawa z dnia 31 stycznia 2019 roku o rodzicielskim świadczeniu uzupełniającym ${ }^{1}$. Jak wskazano $\mathrm{w}$ art. 2 u.o.r.ś.u., celem przedmiotowego świadczenia jest zapewnienie niezbędnych środków utrzymania osobom, które zrezygnowały z zatrudnienia lub innej działalności zarobkowej albo ich nie podjęły ze względu na wychowywanie dzieci. Cel ten został również wyartykułowany w uzasadnieniu projektu ${ }^{2}$. Jednocześnie doszło do nowelizacji kilku innych ustaw, m.in. Kodeksu rodzinnego i opiekuńczego ${ }^{3}$, ustawy z dnia 28 listopada 2003 roku o świadczeniach rodzinnych ${ }^{4}$, ustawy $\mathrm{z}$ dnia 11 lutego 2016 roku o pomocy państwa w wychowaniu dzieci ${ }^{5}$. Tym samym nowy rodzaj świadczenia należy klasyfikować w szeroko rozumianym systemie pomocy socjalnej i finansowej rodzinie.

Dr hab. Piotr Telusiewicz - kierownik Katedry Prawa Rodzinnego i Praw Rodziny, Instytut Prawa, Wydział Prawa, Prawa Kanonicznego i Administracji Katolickiego Uniwersytetu Lubelskiego Jana Pawła II, Al. Racławickie 14, 20-950 Lublin; e-mail: telusiewicz@gmail.com; ORCID: https://orcid.org/0000-0003-1401-7658

${ }^{1}$ Dz.U. z 2019 r., poz. 303 [dalej: u.o.r.ś.u.].

${ }^{2} \mathrm{~W}$ uzasadnieniu wskazano: „Podstawowym celem projektowanej regulacji jest zapewnienie środków utrzymania osobom, które zrezygnowały z zatrudnienia lub go nie podjęły ze względu na wychowywanie dzieci w rodzinach wielodzietnych. Projektowane zmiany podkreślają ważną z punktu widzenia rozwoju kraju funkcję społeczną pełnioną przez rodziców, w większości kobiety, związaną z wychowaniem dzieci”. Druk nr 3157, http://www.sejm.gov.pl [dostęp: 01.06.2019].

${ }^{3}$ Ustawa z dnia 25 lutego 1964 r. - Kodeks rodzinny i opiekuńczy, tekst jednolity: Dz.U. z 2019 r., poz. 2086 [dalej: k.r.o.].

${ }^{4}$ Tekst jednolity: Dz.U. z 2020 r., poz. 111 [dalej: u.o.ś.r.].

${ }^{5}$ Tekst jednolity: Dz.U. z 2019 r., poz. 2407. 
Niniejsze opracowanie ma na celu ocenę prawną przesłanek ustalenia prawa do tego świadczenia. W pierwszej kolejności zostanie dokonany podział przesłanek na pozytywne i negatywne. Następnie, według zaproponowanego podziału i ustawowej kolejności, zostaną zweryfikowane poszczególne przesłanki. Już w tym miejscu należy zaznaczyć, że przedmiotowa ustawa wprowadza katalog przesłanek, które muszą być spełnione łącznie ${ }^{6}$. Tylko wtedy osoba wnioskującego o ustalenie prawa do świadczenia może oczekiwać decyzji pozytywnej. Ponadto, zostaną wyeksponowane także te aspekty, które, w kontekście treści całej ustawy oraz przepisów innych aktów prawnych, mogą być dyskusyjne.

Rodzicielskie świadczenie uzupełniające, $\mathrm{z}$ racji na jego nazwę, kojarzy się ze świadczeniem rodzicielskim, przewidzianym w wymienionej powyżej ustawie o świadczeniach rodzinnych. $Z$ tej racji, w niniejszym opracowaniu, dodatkowo zawarte zostanie odniesienie do tego świadczenia, w celu weryfikacji istnienia lub niepowiązania między tymi dwoma wyróżnionymi świadczeniami.

\section{RODZICIELSKIE ŚWIADCZENIE UZUPEENIAJACEE JAKO ELEMENT SYSTEMU FINANSOWEGO WSPARCIA RODZIN}

Przywołany powyżej ustawowy cel rodzicielskiego świadczenia uzupełniającego sytuuje ten rodzaj świadczenia w szeroko rozumianym systemie finansowego i socjalnego wsparcia rodzin. Zapewnienie niezbędnych środków utrzymania, o którym mowa $\mathrm{w}$ art. 2 u.o.r.ś.u., przybliża również do obowiązku alimentacyjnego ${ }^{7}$, o którym mowa w art. 128 k.r.o. Pamiętać jednak należy, że rodzicielskie świadczenie uzupełniające nie wpływa na zakres świadczeń alimentacyjnych ${ }^{8}$. Można stwierdzić, iż w przypadku rodzicielskiego świadczenia uzupełniającego to Państwo częściowo przejmuje ciężar wypełnienia obowiązku alimentacyjnego dzieci względem rodziców.

Pośród obowiązujących aktów prawnych należących do systemu finansowego i socjalnego wsparcia rodzin, jako istotne, należy wymienić: ustawę z dnia 28 listopada 2003 roku o świadczeniach rodzinnych, ustawę z dnia

\footnotetext{
${ }^{6}$ Por. wyrok Wojewódzkiego Sądu Administracyjnego w Warszawie z dnia 22 sierpnia 2019 r., VIII SA/Wa 398/19, LEX nr 2769463.

${ }^{7}$ Obowiązek dostarczania środków utrzymania, a w miarę potrzeby także środków wychowania (obowiązek alimentacyjny) obciąża krewnych w linii prostej oraz rodzeństwo.

${ }^{8}$ Patrz art. $135 \S 3$ pkt 5 k.r.o.
} 
7 września 2007 roku o pomocy osobom uprawnionym do alimentów ${ }^{9}$, ustawę $\mathrm{z}$ dnia 4 lutego 2011 roku o opiece nad dziećmi w wieku do lat $3^{10}$, ustawę z dnia 9 czerwca 2011 roku o wspieraniu rodziny i systemie pieczy zastępczej ${ }^{11}$, ustawę z dnia 5 grudnia 2014 roku o Karcie Dużej Rodziny ${ }^{12}$, ustawę z dnia 11 lutego 2016 roku o pomocy państwa w wychowaniu dzieci, ustawę z dnia 4 listopada 2016 roku o wsparciu kobiet w ciąży i rodzin „Za życiem”13. Niewątpliwie ustawy te zostały wprowadzone w celu polepszenia warunków finansowych i socjalnych rodziny. Wśród celów tych ustaw wymienia się przecież: zaspokajanie podstawowych, bytowych potrzeb rodziny zapewniających jej członkom życie na poziomie odpowiadającym godności człowieka ${ }^{14} ;$ pomoc państwa osobom uprawnionym do alimentów w przypadku bezskuteczności egzekucji lub niewypłacalności dłużnika alimentacyjnego ${ }^{15}$; realizację funkcji opiekuńczej, wychowawczej i edukacyjnej względem dziecka ${ }^{16}$; skuteczną pomoc dla rodziny przeżywającej trudności w opiekowaniu się i wychowywaniu dzieci oraz skuteczna ochrona dzieci ${ }^{17}$; częściowe pokrycie wydatków związanych $\mathrm{z}$ wychowaniem dziecka ${ }^{18}$; korzystniejszy dostęp do towarów, usług lub innych form działalności dla rodzin ${ }^{19}$; wsparcie kobiet w ciąży ${ }^{20}$.

Analizowana ustawa wpisuje się zatem w katalog ustawowych aktów prawnych, których zadaniem jest polepszenie warunków finansowego i socjalnego funkcjonowania rodziny. Zwraca jednak uwagę fakt, że przedmiotowa ustawa stanowi podstawę dostarczenia niezbędnych środków utrzymania nie rodzicom i dzieciom jednocześnie, ale tylko rodzicom, którzy już wychowali

${ }^{9}$ Tekst jednolity: Dz.U. z 2020 r., poz. 808. Na kwestie dyskusyjne w tym zakresie zwraca uwagę M. Andrzejewski. Patrz M. ANDRZEJEWSKI [w:] Kodeks rodzinny i opiekuńczy. Komentarz, red. H. Dolecki, K. Sokołowski, (Komentarze praktyczne LEX), Wolters Kluwer Polska 2013, s. 922-926.

${ }^{10}$ Tekst jednolity: Dz.U. z 2020 r., poz. 326.

${ }^{11}$ Tekst jednolity: Dz.U. z 2020 r., poz. 821.

12 Tekst jednolity: Dz.U. z 2019 r., poz. 1390.

${ }^{13}$ Tekst jednolity: Dz.U. z 2019 r., poz. 473.

${ }^{14}$ K. MAŁYSA-SulińsKa (red.), A. KAWECKA, J. SAPETA, Ustawa o świadczeniach rodzinnych. Komentarz, (Komentarze praktyczne LEX), Wolters Kluwer Polska 2015.

${ }^{15}$ Szerzej na ten temat E. TOMASZEWSKA, Ustawa o pomocy osobom uprawnionym do alimentów. Komentarz, (Komentarze praktyczne LEX), Lexis Nexis 2014.

${ }^{16}$ Por. na ten temat A. OlSZEWSKI, Ustawa o opiece nad dziećmi w wieku do lat trzech. Komentarz, (Komentarze praktyczne LEX), Wolters Kluwer Polska 2019.

${ }^{17}$ Szeroko na ten temat S. NiteCKI, A. WiLK, Ustawa o wspieraniu rodziny i systemie pieczy zastępczej. Komentarz, (Komentarze praktyczne LEX), Wolters Kluwer Polska 2016.

${ }^{18}$ Zob. Ustawa o pomocy państwa $w$ wychowaniu dzieci. Komentarz, red. J. Blicharz, J. Glumińska-Pawlic, L. Zacharko, LEX/el, Wolters Kluwer 2019.

${ }^{19}$ Patrz art. 1 ustawy z dnia 5 grudnia 2014 r. o Karcie Dużej Rodziny.

${ }^{20}$ Patrz art. 4 ustawy z dnia 4 listopada 2016 r. o wsparciu kobiet w ciąży i rodzin „Za życiem”. 
dzieci. Rodzicielskie świadczenie uzupełniające zatem należy traktować jako swoistego rodzaju rekompensatę dla rodzica, który zrezygnował z pracy zarobkowej na rzecz wychowania dzieci.

\section{PROBLEM ODNIESIENIA DO ŚWIADCZENIA RODZICIELSKIEGO Z USTAWY O ŚWIADCZENIACH RODZINNYCH}

Istotne, w ocenie autora, jest odniesienie do funkcjonującego w ustawie o świadczeniach rodzinnych, a przewidzianego w art. $17 \mathrm{c}$, świadczenia rodzicielskiego. W kontekście prezentowanych zagadnień, jako pierwsze pojawia się pytanie o formalne powiązania lub zależności między świadczeniem rodzicielskim a rodzicielskim świadczeniem uzupełniającym. Pewną pomocą w tym zakresie może być art. 19 u.o.r.ś.u., w którym przewidziano stosowane zmiany w ustawie o świadczeniach rodzinnych ${ }^{21}$. Zmiany jednak nie dotyczą art. 17c u.o.ś.r., o którym będzie mowa poniżej.

Trafnie istotę świadczenia rodzicielskiego zasygnalizowano w jednym z orzeczeń sądu administracyjnego ${ }^{22}$, w którym stwierdzono, że świadczenie rodzicielskie jest pomocą przysługującą $\mathrm{w}$ zamian świadczenia macierzyńskiego dla osób, które nie mogą skorzystać z tego typu świadczenia. Świadczenie rodzicielskie ma zatem charakter zastępczy, ale przede wszystkim zmierza do finansowego wsparcia osób nieubezpieczonych.

Zgodnie $\mathrm{z}$ art. 17c ustawy świadczenie rodzicielskie przysługuje m.in. matce albo ojcu dziecka; opiekunowi faktycznemu dziecka w przypadku objęcia opieką dziecka w wieku do ukończenia 7 roku życia, a w przypadku dziecka, wobec którego podjęto decyzję o odroczeniu obowiązku szkolnego do ukończenia 10 roku życia. W kontekście powyższego należy dodać, za orzecznictwem sądów administracyjnych ${ }^{23}$, że zasadą jest przyznanie świadczenia matce, zaś ojcu na zasadzie wyjątku, jednak zasada pierwszeństwa w otrzymaniu świadczenia dla matki dziecka wynika z uwarunkowań dotyczących procesu wychowania dziecka.

Natomiast $\mathrm{w}$ art. 17c ust. 2 wskazano, że świadczenie rodzicielskie przysługuje ojcu dziecka w przypadku: skrócenia na wniosek matki dziecka okresu

\footnotetext{
${ }^{21}$ Wskazany przepis przewiduje zmiany w zakresie art. 3, 16a, 17 ustawy.

${ }^{22}$ Patrz wyrok Wojewódzkiego Sądu Administracyjnego we Wrocławiu z dnia 19 października 2017 r., IV SA/Wr 286/17, LEX nr 2400744.

${ }^{23}$ Wyrok Naczelnego Sądu Administracyjnego z dnia 7 lutego 2018 r., I OSK 1893/17, LEX nr 2612677.
} 
pobierania świadczenia rodzicielskiego, zasiłku macierzyńskiego lub uposażenia za okres ustalony przepisami Kodeksu pracy jako okres urlopu macierzyńskiego, okres urlopu na warunkach urlopu macierzyńskiego lub okres urlopu rodzicielskiego, po wykorzystaniu przez nią tego świadczenia, zasiłku lub uposażenia za okres co najmniej 14 tygodni od dnia urodzenia dziecka; śmierci matki dziecka; porzucenia dziecka przez matkę.

Przedstawiane świadczenie rodzicielskie ma charakter okresowy i przysługuje, odpowiednio do przypadków przewidzianych w ustawie, przez okres 52 tygodni (w przypadku urodzenia jednego dziecka przy jednym porodzie, przysposobienia jednego dziecka lub objęcia opieką jednego dziecka); 65 tygodni (w przypadku urodzenia dwojga dzieci przy jednym porodzie, przysposobienia dwojga dzieci lub objęcia opieką dwojga dzieci); 67 tygodni (w przypadku urodzenia trojga dzieci przy jednym porodzie, przysposobienia trojga dzieci lub objęcia opieką trojga dzieci); 69 tygodni (w przypadku urodzenia czworga dzieci przy jednym porodzie, przysposobienia czworga dzieci lub objęcia opieką czworga dzieci); 71 tygodni (w przypadku urodzenia pięciorga i więcej dzieci przy jednym porodzie, przysposobienia pięciorga i więcej dzieci lub objęcia opieką pięciorga i więcej dzieci).

Ustawa wskazuje również, że świadczenie rodzicielskie nie przysługuje, jeżeli co najmniej jeden z uprawnionych otrzymuje zasiłek macierzyński lub uposażenie za okres ustalony przepisami Kodeksu pracy jako okres urlopu macierzyńskiego, okres urlopu na warunkach urlopu macierzyńskiego lub okres urlopu rodzicielskiego; dziecko zostało umieszczone w pieczy zastępczej; osoba ubiegająca się o świadczenie rodzicielskie lub osoba pobierająca świadczenie rodzicielskie nie sprawuje lub zaprzestała sprawowania osobistej opieki nad dzieckiem, w tym w związku z zatrudnieniem lub wykonywaniem innej pracy zarobkowej, które uniemożliwiają sprawowanie tej opieki; w związku z wychowywaniem tego samego dziecka lub w związku z opieką nad tym samym dzieckiem jest już ustalone prawo do świadczenia rodzicielskiego, dodatku do zasiłku rodzinnego z tytułu opieki nad dzieckiem w okresie korzystania z urlopu wychowawczego, świadczenia pielęgnacyjnego, specjalnego zasiłku opiekuńczego lub zasiłku dla opiekuna, o którym mowa w ustawie z dnia 4 kwietnia 2014 roku o ustaleniu i wypłacie zasiłków dla opiekunów ${ }^{24}$; osobom uprawnionym przysługuje za granicą świadczenie o podobnym charakterze do

\footnotetext{
${ }^{24}$ Tekst jednolity: Dz.U. z 2017 r., poz. 2092 z późn. zm.
} 
świadczenia rodzicielskiego, chyba że przepisy o koordynacji systemów zabezpieczenia społecznego lub dwustronne umowy o zabezpieczeniu społecznym stanowią inaczej.

Podsumowując powyższe, należy wskazać, iż rodzicielskie świadczenie uzupełniające nie jest formalnie związane $\mathrm{z}$ przedstawionym świadczeniem rodzinnym. Można jednak stwierdzić, iż wprowadzenie ustawy o rodzicielskim świadczeniu uzupełniającym stało się swoistego rodzaju dopełnieniem katalogu instytucji z zakresu finansowego wsparcia matki lub ojca wychowujących dziecko, przy czym świadczenie rodzicielskie i rodzicielskie świadczenie uzupełniające znajdują się na skrajnych pozycjach tego katalogu. Dobrze się zatem stało, że ustawodawca zapewnia w tym momencie, co do zasady, kompleksowe wsparcie finansowe dla matki lub ojca wychowujących dziecko.

\section{KATALOG PRZESŁANEK DO USTALENIA PRAWA DO RODZICIELSKIEGO ŚWIADCZENIA UZUPEŁNIAJĄCEGO}

Dokonując weryfikacji treści omawianej ustawy, można dostrzec i zaproponować podział przesłanek do ustalenia prawa do rodzicielskiego świadczenia uzupełniającego na przesłanki pozytywne i negatywne. Wśród przesłanek pozytywnych należy wymienić: przesłankę macierzyństwa i ojcostwa ${ }^{25}$; przesłankę urodzenia i wychowania lub wychowania ${ }^{26}$; przesłankę wychowania określonej liczby dzieci ${ }^{27}$; przesłankę uzyskania określonego wieku ${ }^{28}$; przesłankę braku dochodu ${ }^{29}$; przesłankę ośrodka interesów życiowych ${ }^{30}$. Natomiast przesłankami negatywnymi są: przesłanka pozbawienia lub ograniczenia władzy rodzicielskiej ${ }^{31}$; przesłanka długotrwałego zaprzestania wychowania dzieci $^{32}$; przesłanka zaistnienia tymczasowego aresztowania lub pozbawienia wolności ${ }^{33}$; przesłanka posiadania uprawnienia do emerytury lub renty ${ }^{34}$. W związku z dokonanym podziałem, w dalszej części opracowania zostaną omówione poszczególne przesłanki.

\footnotetext{
${ }^{25}$ Art. 3 ust. 1 u.o.r.ś.u.

26 Tamże.

27 Tamże.

${ }^{28}$ Art. 3 ust. 3 u.o.r.ś.u.

29 Tamże.

${ }^{30}$ Art. 3 ust. 2 u.o.r.ś.u.

${ }^{31}$ Art. 5 ust. 3 u.o.r.ś.u.

32 Tamże.

${ }^{33}$ Art. 3 ust. 6 u.o.r.ś.u.

${ }^{34}$ Art. 3 ust. 9 u.o.r.ś.u.
} 
Pierwsza przesłanka wynika ze stanu macierzyństwa lub ojcostwa. Nie ulega wątpliwości, że dla rozumienia pojęć użytych w art. 3 ust. 1 u.o.r.ś.u, tj. „matka” oraz „ojciec”, należy posługiwać się odpowiednio przepisami art. $61^{9}-86$ k.r.o. Zgodnie więc $\mathrm{z}$ art. 3 ust. 1 u.o.r.ś.u. świadczenie może być przyznane dwóm osobom. Pierwsza z nich to matka, która urodziła i wychowała lub wychowała co najmniej czworo dzieci. Druga z nich to ojciec, który wychował co najmniej czworo dzieci, w przypadku śmierci matki dzieci albo porzucenia dzieci przez matkę lub w przypadku długotrwałego zaprzestania wychowywania dzieci przez matkę.

W przypadku matki zwraca uwagę połączenie „urodziła i wychowała”. Dla oceny instytucji macierzyństwa ${ }^{35}$, zwłaszcza w kontekście obowiązujących przepisów k.r.o, jest to nowość. Należy ją ocenić bardzo pozytywnie, zwłaszcza z tego względu, że w art. 2 pkt 9 u.o.ś.r.u. podano definicję ustawową „wychowania". Przez wychowanie rozumie się w ustawie sprawowanie osobistej opieki nad dziećmi polegającej na stałym, bezpośrednim i ciągłym wykonywaniu ogółu obowiązków spoczywających na rodzicach w ramach praw im przysługujących względem dzieci w celu należytego sprawowania pieczy nad nimi i nad ich majątkiem ${ }^{36}$. Tak szczegółowych sformułowań trudno doszukać się w k.r.o, choć warto w tym miejscu wskazać, iż zaprezentowana treść pozostaje w zgodności z art. 95-96 k.r.o. ${ }^{37}$ (czyli tych odnoszących się do władzy rodzicielskiej). Właśnie w kontekście wychowania oraz występującej tu relacji zjawisk „ciągłości” i „długotrwałości”, wypowiedział się w jednym orzeczeniu sąd administracyjny ${ }^{38}$. W uzasadnieniu wyroku wskazano, że nieuprawnione jest stanowisko organu co do tego, że proces wychowania ma być procesem długotrwałym. Długotrwałość nie jest bowiem synonimem stałości ani ciągłości. Pewien stan może mieć charakter stały, czyli nieulegający zmianom, albo trwający bez przerwy, nawet jeżeli zamknął się w niedługim czasie. Ta sama uwaga dotyczy pojęcia ciągłości.

${ }^{35}$ Patrz art. 61 [9]-61 [16] k.r.o.

${ }^{36} \mathrm{~W}$ uzasadnieniu projektu wskazano, że: „Trudno więc określić ramy czasowe wychowania, o którym mowa w projektowanej ustawie. Stąd też każdy wniosek o świadczenie będzie szczegółowo rozpatrywany indywidualnie”. Druk nr 3157, http://www.sejm.gov.pl [dostęp: 01.06.2019].

37 Art. 95 § 1 k.r.o stanowi, że władza rodzicielska obejmuje w szczególności obowiązek i prawo rodziców do wykonywania pieczy nad osobą i majątkiem dziecka oraz do wychowania dziecka, z poszanowaniem jego godności i praw. Z kolei art. 96 § 1 k.r.o. wskazuje, że rodzice wychowują dziecko pozostające pod ich władzą rodzicielską i kierują nim. Ciekawie komentuje te przepisy T. Smyczyński. Patrz szerzej: T. SMYCZYŃSKI, Prawo rodzinne i opiekuńcze, Warszawa: Wydawnictwo C.H. Beck 2016, s. 237-238.

${ }^{38}$ Wyrok Wojewódzkiego Sądu Administracyjnego w Warszawie z dnia 15 listopada 2019 r., II SA/Wa 1432/19, LEX nr 2865521. 
W przypadku ojca zwracają uwagę dwa aspekty. Przede wszystkim nie ma znaczenia dla weryfikacji tego kryterium sposób powstania relacji rodzinno-prawnej ojcostwa. Każdy z trzech przewidzianych w k.r.o. sposobów ustalenia ojcostwa, a także przysposobienie dziecka przez mężczyznę, może być podstawą uzyskania statusu ojca przez określonego mężczyznę. Ze względu na wskazane sposoby nie dochodzi, na płaszczyźnie omawianej ustawy, do różnicowania uprawnienia ojca. Dostrzec również należy aspekt swoistego rodzaju „samotnego wychowania” określonej liczby dzieci. W przypadku matki nie ma tego wymogu. Przepis został skonstruowany w ten sposób, że dla przyznania rodzicielskiego świadczenia uzupełniającego nie ma znaczenia, czy matka wychowywała dzieci wraz ojcem, czy też nie. W przypadku ojca przewidziano dwa rodzaje przyczyn „samotnego wychowania”, tj. przyczyna naturalna (śmierć matki) oraz przyczyna zawiniona po stronie matki (porzucenie dzieci przez matkę lub długotrwałe zaprzestanie wychowywania dzieci przez matkę)

W kontekście tak zarysowanej problematyki pojawiają się istotne pytania dotyczące kwestii rozwiązania małżeństwa przez rozwód, pozostawania przez małżonków w separacji prawnej lub faktycznej, a w konsekwencji wpływu tych zdarzeń na wychowanie dzieci przez matkę lub ojca. W ocenie autora przypadki związane z „samotnym wychowaniem” dzieci przez matkę lub ojca (rozwiedzionych lub separowanych) mogą być problematyczne w zakresie oceny spełnienia kryterium „wychowania” - zwłaszcza w rozumieniu analizowanej ustawy.

Warto również zauważyć, że w art. 2 pkt 1 u.o.r.ś.u. wskazano na definicję dziecka. Na potrzeby tejże ustawy przez dziecko rozumie się dziecko własne lub współmałżonka, lub dziecko przysposobione, lub przyjęte na wychowanie $\mathrm{w}$ ramach rodziny zastępczej, z wyjątkiem rodziny zastępczej zawodowej. $\mathrm{W}$ ocenie autora dostrzegalna jest jedna wada przywołanej definicji. Zgodnie z art. 3 ust. 1 u.o.r.ś.u. matka może uzyskać świadczenie, gdy urodziła i wychowała co najmniej czworo dzieci. Oznaczać to będzie, że matka, która urodziła trójkę dzieci, a wychowała czwórkę dzieci (tj. troje własnych oraz jedno współmałżonka), nie będzie mogła otrzymać rodzicielskiego świadczenia uzupełniającego. Pogląd ten wynika z treści ustawy, tj. „urodziła i wychowała lub wychowała”, która może prowadzić do wniosku, że „wychowała” odnosi się jedynie do dzieci, których określona kobieta nie urodziła. W konsekwencji rodzicielskie świadczenie uzupełniające może otrzymać kobieta, która urodziła i wychowała określoną liczbę dzieci lub jedynie wychowała (tj. nie urodziła) określoną liczbę dzieci. Z ustawy nie wynika, że opisane dwa przypadki mogą być łączone (tj. część dzieci urodzonych i wychowanych, a część dzieci 
tylko wychowanych). Inaczej będzie w przypadku ojca (przy którym przecież nie występuje element urodzenia), który „samotnie wychowywał” czwórkę dzieci (tj. troje własnych i jedno współmałżonka).

W odniesieniu do opisywanego wyżej zjawiska „samotnego wychowania”, kolejny raz powraca kwestia istnienia małżeństwa między ojcem a matką określonego dziecka. Nabiera ona znaczenia w przypadku dziecka współmałżonka (o którym mowa w przywołanej wyżej definicji dziecka). Wracając zatem do art. 3 ust. 1 u.o.r.ś.u., należy wskazać, że trudno będzie w kontekście aspektu formalnego trwania małżeństwa (przy którym faktycznie nie istnieje wspólne pożycie małżonków) i wychowania dzieci własnych i współmałżonka (lub tylko dzieci współmałżonka) wykazać okoliczność osobistej opieki nad dziećmi (o której mowa w definicji wychowania).

Wymienione powyżej przesłanki pozytywne ustalenia prawa do rodzicielskiego świadczenia uzupełniającego tracą na znaczeniu w przypadku wystąpienia przesłanek negatywnych. Art. 3 ust. 5 wskazuje, że organ może odmówić przyznania świadczenia osobie, którą sąd pozbawił władzy rodzicielskiej lub której sąd ograniczył władzę rodzicielską przez umieszczenie dziecka lub dzieci w pieczy zastępczej. Ponadto możliwość ta dotyczy przypadku długotrwałego zaprzestania wychowywania dzieci. Przepis został sformułowany w jasny sposób, jeśli chodzi o kwestię fakultatywności jego zastosowania. Wyrażenie „może” oznacza, że organ mimo wystąpienia przesłanek negatywnych może przyznać świadczenie.

W ocenie autora prezentowane rozwiązanie nie jest prawidłowe. Istota rodzicielskiego świadczenia uzupełniającego oraz przesłanki pozytywne przyznania tego świadczenia jednoznacznie przesądzają, iż wychowywanie dzieci (w przypadku kobiet również urodzenie dzieci) ma kluczowe znaczenie dla przyznania tego świadczenia.

Kierując się tą kluczową przesłanką, należy wskazać, iż zdecydowanie korzystniejsze byłoby rozwiązanie, w którym organ musiałby odmówić przyznania świadczenia osobie, którą sąd pozbawił władzy rodzicielskiej lub której sąd ograniczył władzę rodzicielską przez umieszczenie dziecka lub dzieci w pieczy zastępczej. Pośrednio, przedstawione rozwiązanie, koresponduje z art. 3 ust. 6 u.o.r.ś.u., w którym wskazano, że świadczenie nie przysługuje osobie, która jest tymczasowo aresztowana lub odbywa karę pozbawienia wolności. Kierując się treścią wskazanego przepisu, można podnosić, iż ustawodawcy zależało przede wszystkim na tym, aby określona osoba faktycznie, czynnie i skutecznie wychowywała dzieci. Osoba pozbawiona władzy rodzicielskiej nie może faktycznie wychowywać dzieci. To samo dotyczy sytuacji 
ograniczenia władzy rodzicielskiej w postaci umieszczenia dziecka lub dzieci w pieczy zastępczej. Choć w tym przypadku można dodatkowo postawić pytanie, czy „umieszczenie dziecka lub dzieci” oznacza wszystkie dzieci z danej rodziny, czy tylko część z nich (przykładowo pięcioro z ośmiorga). Na tym etapie rozważań wydaje się, że organ odmawiałby świadczenia tylko w przypadku umieszczenia części dzieci w pieczy zastępczej.

W przypadku długotrwałego zaprzestania wychowywania dzieci zasadne byłoby pozostanie przy obecnym rozwiązaniu, gdyż ocena stanu długotrwałego zaprzestania wychowania dzieci musi być poprzedzona oceną okoliczności, które do tego stanu doprowadziły. Pozostawienie zatem możliwości podjęcia przez organ decyzji pozytywnej lub negatywnej na podstawie oceny całokształtu okoliczności jest rozwiązaniem słusznym.

Należy zauważyć, że kwestia wychowania dzieci stała się okolicznością rozważaną przez sądy administracyjne w sprawach dotyczących rodzicielskiego świadczenia uzupełniającego. W uzasadnieniu wyroku sądu administracyjnego ${ }^{39}$ wskazano, że wyłączenia prawa do rodzicielskiego świadczenia uzupełniającego potwierdzają tezę, że przesłanka wychowania dziecka, określona w art. 3 ust. 1 pkt 1 u.o.r.ś.u., może być spełniona również wówczas, gdy wychowywanie ustało wraz z ustaniem władzy rodzicielskiej przed uzyskaniem przez dziecko pełnoletności.

Ciekawe rozważania można podjąć w kontekście art. 3 ust. 6 u.o.r.ś.u., który stanowi, że świadczenie nie przysługuje osobie, która jest tymczasowo aresztowana lub odbywa karę pozbawienia wolności. Przepis ten oznacza, że wniosku takiego nie może złożyć osoba, która aktualnie pozostaje w warunkach izolacji. Ustawa ponadto, w art. 3 ust. 8, nakłada obowiązek na osobę otrzymującą rodzicielskie świadczenie uzupełniające, by niezwłocznie powiadomić organ rentowy o tymczasowym aresztowaniu lub o odbywaniu kary pozbawienia wolności.

Biorąc powyższe pod uwagę, można przykładowo wskazać, iż w sytuacji warunkowego zawieszenia kary pozbawienia wolności ${ }^{40}$, zwolnienia tymczasowo

${ }^{39}$ Wyrok Wojewódzkiego Sądu Administracyjnego w Warszawie z dnia 24 stycznia 2020 r., II SA/Wa 1491/19, LEX nr 2940150. Podobną tezę zawarto w uzasadnieniu wyroku Wojewódzkiego Sądu Administracyjnego w Warszawie z dnia 18 września 2019 r., II SA/Wa 1064/19, LEX nr 2865985. Wskazano $\mathrm{w}$ nim, że $\mathrm{z}$ ustawowej definicji wychowania wynika, że określone tam działania składające się na wychowanie odnoszą się do dziecka w każdym wieku, również do dziecka bardzo małego. Nie ma zatem żadnych przeszkód, aby przyjąć, że matka wychowała dziecko nawet wtedy, gdy wychowywanie zostało przerwane (zakończyło się) wskutek śmierci dziecka w wieku niemowlęcym.

${ }^{40}$ Art. 69 § 1 ustawy z dnia 6 czerwca 1997 r. - Kodeks karny, tekst jednolity: Dz.U. z 2019 r., poz. 1950 [dalej: k.k.]. Przepis ten stanowi, że sąd może warunkowo zawiesić wykonanie kary 
aresztowanego ${ }^{41}$ lub zakończenia odbywania kary pozbawienia wolności, osoba spełniająca ustawowe przesłanki może ubiegać się o przyznanie rodzicielskiego świadczenia uzupełniającego. W ocenie autora przepisy ustawy nie są odpowiednio skonstruowane. Fakt tymczasowego aresztowania lub odbywania kary pozbawienia wolności nie powinien mieć znaczenia wobec osób, które spełniły wszystkie warunki do uzyskania rodzicielskiego świadczenia uzupełniającego. Można bowiem przyjąć, iż posiadający ustawowo przewidziany wiek kobieta (w wieku powyżej 60 lat) i mężczyzna (w wieku powyżej 65 lat) spełnili podstawowy wymóg, tj. wychowali już co najmniej czworo dzieci.

Można się również zastanawiać, czy w przypadku warunkowego przedterminowego zwolnienia osoba uprawniona może ubiegać się o przyznanie świadczenia. Wydaje się, że tak. Osoba ta nie jest już pozbawiona wolności, na co wskazuje istota warunkowego przedterminowego zwolnienia ${ }^{42}$. Jednoznacznie należy rozstrzygnąć, że w przypadku przerwy w wykonaniu kary pozbawienia wolności ${ }^{43}$ takiej możliwości nie będzie, nawet jeśli przerwa miałaby nastąpić ze względów rodzinnych ${ }^{44}$. Dyskusyjna pozostaje kwestia odroczenia kary pozbawienia wolności (zarówno w zakresie obligatoryjnym ${ }^{45}$, jak i fakultatywnym ${ }^{46}$ ), choć w tym przypadku autor skłania się do poglądu, że

pozbawienia wolności orzeczonej w wymiarze nieprzekraczającym roku, jeżeli sprawca w czasie popełnienia przestępstwa nie był skazany na karę pozbawienia wolności i jest to wystarczające dla osiągnięcia wobec niego celów kary, a w szczególności zapobieżenia powrotowi do przestępstwa.

${ }^{41}$ Art. $264 \S 1$ ustawy z dnia 6 czerwca 1997 r. - Kodeks postępowania karnego, tekst jednolity: Dz.U. z 2020 r., poz. 30. Przepis określa, że w razie uniewinnienia oskarżonego, umorzenia lub warunkowego umorzenia postępowania, warunkowego zawieszenia wykonania kary, wymierzenia kary pozbawienia wolności odpowiadającej co najwyżej okresowi tymczasowego aresztowania, skazania na karę łagodniejszą, niż pozbawienie wolności albo w razie odstąpienia od wymierzenia kary, zarządza się niezwłoczne zwolnienie tymczasowo aresztowanego, jeżeli nie jest on pozbawiony wolności w innej sprawie.

${ }^{42}$ Art. 77 § 1 k.k. W przepisie wskazano, że skazanego na karę pozbawienia wolności sąd może warunkowo zwolnić z odbycia reszty kary tylko wówczas, gdy jego postawa, właściwości i warunki osobiste, okoliczności popełnienia przestępstwa oraz zachowanie po jego popełnieniu i w czasie odbywania kary uzasadniają przekonanie, że skazany po zwolnieniu będzie stosował się do orzeczonego środka karnego lub zabezpieczającego i przestrzegał porządku prawnego, w szczególności nie popełni ponownie przestępstwa.

43 Art. $153 \S 1$ ustawy z dnia 6 czerwca 1997 r. - Kodeks karny wykonawczy, tekst jednolity: Dz.U. z 2020 r., poz. 523 [dalej: k.k.w.]. Kodeks stanowi, że sąd penitencjarny udziela przerwy w wykonaniu kary w wypadku określonym w art. $150 \S 1$ do czasu ustania przeszkody.

${ }^{44}$ Art. $153 \S 2$ k.k.w. stanowi, że sąd penitencjarny może udzielić przerwy w wykonaniu kary pozbawienia wolności, jeżeli przemawiają za tym ważne względy rodzinne lub osobiste.

${ }^{45}$ Art. $150 \S 1$ k.k.w. stanowi, że wykonanie kary pozbawienia wolności w wypadku choroby psychicznej lub innej ciężkiej choroby uniemożliwiającej wykonywanie tej kary sąd odracza do czasu ustania przeszkody.

${ }^{46}$ Art. $150 \S 2$ k.k.w. wskazuje, że sąd może odroczyć wykonanie kary pozbawienia wolności na okres do roku, jeżeli natychmiastowe wykonanie kary pociągnęłoby dla skazanego lub jego 
osoba korzystająca z odroczenia nie może skutecznie złożyć wniosku o przyznanie rodzicielskiego świadczenia uzupełniającego.

Do powyższych wniosków skłania również treść art. 3 ust. 7 u.o.r.ś.u., w którym wskazano, że powyższego zakazu nie stosuje się do osób odbywających karę pozbawienia wolności w systemie dozoru elektronicznego ${ }^{47}$. Wskazany przepis koresponduje z przepisami dotyczącymi warunków odbycia kary pozbawienia wolności w systemie dozoru elektronicznego, a szczególnie jednego z nich, tj. warunku, iż skazany posiada określone miejsce stałego pobytu (co może prowadzić do ciekawych rozważań w kontekście tzw. ośrodka interesów życiowych, o którym mowa w u.o.r.ś.u.). Oznaczać to będzie, że osoby odbywające karę pozbawienia wolności w systemie umożliwiającym wychowywanie dziecka lub dzieci (przynajmniej częściowo), mogą korzystać z rodzicielskiego świadczenia uzupełniającego.

Z racji na wcześniej zarysowaną problematykę, warto w tym miejscu odnieść się do art. 3 ust. 3 u.o.r.ś.u. Przepis stanowi, że rodzicielskie świadczenie uzupełniające może być przyznane matce po osiągnięciu wieku 60 lat albo ojcu po osiągnięciu wieku 65 lat, w przypadku gdy nie posiada dochodu zapewniającego niezbędne środki utrzymania. Wskazane kryterium koresponduje z rozwiązaniami zawartymi w ustawach emerytalnych ${ }^{48}$, w tym zwłaszcza w odniesieniu do wieku. Choć nie należy zapominać, iż w art. 2 pkt 3 u.o.r.ś.u. wyliczono katalog emerytur i rent, które należy uwzględniać przy stosowaniu ustawy. Takie rozwiązanie jest jednoznacznym potwierdzeniem dążenia ustawodawcy do zapewnienia utrzymania osobom, które ze względu na wychowanie dzieci zrezygnowały z zatrudnienia lub innej działalności zarobkowej albo ich nie podjęły i w ten sposób nie nabyły uprawnień emerytalnych.

Jednocześnie ustawa w art. 2 pkt 2 u.o.r.ś.u. stanowi, co należy rozumieć przez dochód. Podając w uproszczeniu (ze względu na zakres treściowy

rodziny zbyt ciężkie skutki. W stosunku do skazanej kobiety ciężarnej oraz osoby skazanej samotnie sprawującej opiekę nad dzieckiem sąd może odroczyć wykonanie kary na okres do 3 lat po urodzeniu dziecka.

${ }^{47}$ Art. 43la k.k.w. Przepis określa, że sąd penitencjarny może udzielić skazanemu zezwolenia na odbycie kary pozbawienia wolności w systemie dozoru elektronicznego, jeżeli zostały spełnione łącznie następujące warunki: wobec skazanego orzeczono karę pozbawienia wolności nieprzekraczająca jednego roku i 6 miesięcy, a nie zachodza warunki przewidziane w art. 64 § 2 Kodeksu karnego; jest to wystarczające do osiągnięcia celów kary; skazany posiada określone miejsce stałego pobytu; osoby pełnoletnie zamieszkujące wspólnie ze skazanym wyraziły zgodę, o której mowa w art. $43 \mathrm{~h} \S 3$; odbywaniu kary pozbawienia wolności w systemie dozoru elektronicznego nie stoją na przeszkodzie warunki techniczne, o których mowa w art. $43 \mathrm{~h} \S 1$.

${ }^{48}$ Zob. art. 24 ustawy z dnia 17 grudnia 1998 r. o emeryturach i rentach z Funduszu Ubezpieczeń Społecznych, tekst jednolity: Dz.U. z 2020 r., poz. 53. 
definicji dochodu), przez dochód należy rozumieć: przychody podlegające opodatkowaniu na zasadach określonych $\mathrm{w}$ ustawie o podatku dochodowym od osób fizycznych; dochód z działalności podlegającej opodatkowaniu na podstawie przepisów o zryczałtowanym podatku dochodowym od niektórych przychodów osiąganych przez osoby fizyczne; inne dochody niepodlegające opodatkowaniu na podstawie przepisów o podatku dochodowym od osób fizycznych. Przy czym w tym ostatnim przypadku ustawodawca wymienił obszerny zbiór tego rodzaju dochodów.

Powyższe rozważania znajdują również oparcie w art. 3 ust. 9 u.o.r.ś.u. Wskazano w nim, że świadczenie nie przysługuje osobie uprawnionej do emerytury lub renty w wysokości co najmniej najniższej emerytury. Na uwagę zasługuje druga część omawianej przesłanki negatywnej, czyli odniesienie do wysokości renty (a tym samym poziomu najniższej emerytury). Świadczy ona bowiem o istocie rodzicielskiego świadczenia uzupełniającego, które nie jest dodatkiem do osiąganego dochodu (co mógłby sugerować w tym przypadku wyraz ,uzupełniające”), ale ma na celu zapewnienie jakiegokolwiek dochodu dla osoby, która go nie uzyskuje.

Zgodnie z art. 3 ust. 2 u.o.r.ś.u. świadczenie może być przyznane matce lub ojcu (do których odnoszono się powyżej) zamieszkującym na terytorium Rzeczypospolitej Polskiej i posiadającym po ukończeniu 16 roku życia centrum interesów osobistych lub gospodarczych (tzw. ośrodek interesów życio$w_{y c h}{ }^{49}$ ) na terytorium Rzeczypospolitej Polskiej przez okres co najmniej dziesięciu lat. Dodatkowo, musi być spełniony kolejny warunek. Osoby te muszą być obywatelami Rzeczypospolitej Polskiej lub posiadającymi prawo pobytu, lub prawo stałego pobytu na terytorium Rzeczypospolitej Polskiej obywatelami państw członkowskich Unii Europejskiej, państw członkowskich Europejskiego Porozumienia o Wolnym Handlu (EFTA) - stron umowy o Europejskim Obszarze Gospodarczym lub Konfederacji Szwajcarskiej, lub cudzoziemcami legalnie przebywającymi na terytorium Rzeczypospolitej Polskiej. $\mathrm{W}$ art. 3 ust. 4 u.o.r.ś.u. ponadto wskazano, że świadczenie przysługuje pod warunkiem zamieszkiwania na terytorium Rzeczypospolitej Polskiej w trakcie jego pobierania.

\footnotetext{
${ }^{49}$ Patrz art. 3 ust. 1a pkt 1 ustawy z dnia 26 lipca 1991 r. o podatku dochodowym od osób fizycznych, tekst jednolity: Dz.U. z 2019 r., poz. 1387. Przepis ten stanowi, że za osobę mającą miejsce zamieszkania na terytorium Rzeczypospolitej Polskiej uważa się osobę fizyczną, która posiada na terytorium Rzeczypospolitej Polskiej centrum interesów osobistych lub gospodarczych (ośrodek interesów życiowych).
} 
Powyższe rozwiązanie należy ocenić pozytywnie. Przekazywanie określonych środków finansowych, w ramach rodzicielskiego świadczenia uzupełniającego, powinno odbywać się względem osób, które zrezygnowały z zatrudnienia lub innej działalności zarobkowej albo ich nie podjęły ze względu na wychowywanie dzieci, a wychowania podjęły się w Polsce i dla dobra polskiego społeczeństwa. Wydaje się, że tego typu tendencja dominowała również przy formułowaniu wymogu zamieszkiwania na terytorium Rzeczypospolitej Polskiej $\mathrm{w}$ trakcie pobierania świadczenia.

\section{WNIOSKI}

Rodzicielskie świadczenie uzupełniające wpisuje się w katalog istniejących aktów prawnych, które tworzą szeroko rozumiany system finansowego i socjalnego wsparcia rodziny. Mimo opisanej częściowej zbieżności terminologicznej, omówione świadczenie nie jest w jakikolwiek sposób powiązane ze świadczeniem rodzicielskim przewidzianym w ustawie o świadczeniach rodzinnych. Oba świadczenia, choć ich cel jest niemalże identyczny, skonstruowane są na innych zasadach i dotyczą osób znajdujących się w diametralnie różnych sytuacjach rodzinnych i życiowych.

W związku z powyższą uwagą, autor niniejszego opracowania wyraża przekonanie, że określenie „rodzicielskie świadczenie uzupełniające” jest niewłaściwe. Może bowiem prowadzić do wniosku, iż prezentowane świadczenie ma na celu uzupełnienie świadczenia rodzicielskiego z ustawy o świadczeniach rodzinnych. $Z$ pewnością trafniejszym określeniem byłoby „świadczenie wychowawcze uzupełniające”, które w pełniejszy sposób korespondowałoby w najistotniejszą przesłanką przyznania omawianego świadczenia, czyli wychowaniem dzieci. Niestety, mogłoby ono nawiązywać mylnie do świadczenia wychowawczego, o którym mowa we wspomnianej wcześniej ustawie z 11 lutego 2016 r. o pomocy państwa w wychowaniu dzieci. Wydaje się zatem, że właściwym rozwiązaniem byłoby przyjęcie określenia „świadczenie uzupełniające dla rodziców", które nawiązuje do podstawowego celu ustawy.

Nie można jednak stwierdzić, iż wprowadzenie rodzicielskiego świadczenia uzupełniającego było błędem ustawodawcy. Jak wskazano we wcześniejszych rozważaniach, wprowadzone rozwiązanie należy ocenić pozytywnie. Dopełnia ono bowiem katalog finansowego wsparcia matki lub ojca wychowującego dziecko i prowadzi do powstania kompleksowego mechanizmu tego wsparcia. 
Sposób sformułowania przesłanek pozytywnych i negatywnych uzyskania rodzicielskiego świadczenia uzupełniającego można ocenić pozytywnie. W kontekście przeprowadzonej analizy należałoby podjąć szersze badania $\mathrm{w}$ odniesieniu do pierwszej przesłanki, tj. macierzyństwa i ojcostwa, a ponadto problemu pozostawania matki lub ojca w związku małżeńskim.

Nie ulega wątpliwości, iż należy również podjąć dyskusję w przedmiocie wpływu wykonywania kary pozbawienia wolności na możliwość złożenia wniosku o rodzicielskie świadczenie uzupełniające. Przeprowadzona powyżej przykładowa weryfikacja w tym zakresie wskazuje, że ustawowe sformułowanie: „odbywa karę pozbawienia wolności” może wywoływać pewne wątpliwości zarówno w kontekście ubiegania się o przyznanie świadczenia, jak też i w kontekście obowiązku niezwłocznego powiadomienia organu rentowego o odbywaniu kary pozbawienia wolności.

\section{BIBLIOGRAFIA}

ŹRÓDŁA PRAWA

Ustawa z dnia 25 lutego 1964 r. - Kodeks rodzinny i opiekuńczy, tekst jednolity: Dz.U. z 2019 r., poz. 2086.

Ustawa z dnia 26 lipca 1991 r. o podatku dochodowym od osób fizycznych, tekst jednolity: Dz.U. z 2019 r., poz. 1387.

Ustawa z dnia 6 czerwca 1997 r. - Kodeks karny, tekst jednolity: Dz.U. z 2019 r., poz. 1950.

Ustawa z dnia 6 czerwca 1997 r. - Kodeks postępowania karnego, tekst jednolity: Dz.U. z 2020 r., poz. 30 .

Ustawa z dnia 6 czerwca 1997 r. - Kodeks karny wykonawczy, tekst jednolity: Dz.U. z 2020 r., poz. 523.

Ustawa z dnia 17 grudnia 1998 r. o emeryturach i rentach z Funduszu Ubezpieczeń Społecznych, tekst jednolity: Dz.U. z 2020 r., poz. 53.

Ustawa z dnia 28 listopada 2003 r. oświadczeniach rodzinnych, tekst jednolity: Dz.U. z 2020 r., poz. 111 .

Ustawa z dnia 7 września 2007 r. o pomocy osobom uprawnionym do alimentów, tekst jednolity: Dz.U. z 2020 r., poz. 808.

Ustawa z dnia 4 lutego 2011 r. o opiece nad dziećmi w wieku do lat 3, tekst jednolity: Dz.U. z 2020 r., poz. 326.

Ustawa z dnia 9 czerwca 2011 r. o wspieraniu rodziny i systemie pieczy zastępczej, tekst jednolity: Dz.U. z 2020 r., poz. 821.

Ustawa z dnia 4 kwietnia 2014 r. o ustaleniu i wypłacie zasiłków dla opiekunów, tekst jednolity: Dz.U. z 2017 r., poz. 2092 z późn. zm..

Ustawa z dnia 5 grudnia 2014 r. o Karcie Dużej Rodziny, tekst jednolity: Dz.U. z 2019 r., poz. 1390. 
Ustawa z dnia 11 lutego 2016 r. o pomocy państwa w wychowaniu dzieci, tekst jednolity: Dz.U. z 2019 r., poz. 2407.

Ustawa z dnia 4 listopada 2016 r. o wsparciu kobiet w ciąży i rodzin „Za życiem” tekst jednolity: Dz.U. z 2019 r., poz. 473

Ustawa z dnia 31 stycznia 2019 r. o rodzicielskim świadczeniu uzupełniającym, Dz.U. z 2019 r., poz. 303

\section{ORZECZENIA}

Wyrok Wojewódzkiego Sądu Administracyjnego we Wrocławiu z dnia 19 października 2017 r., IV SA/Wr 286/17, LEX nr 2400744.

Wyrok Naczelnego Sądu Administracyjnego z dnia 7 lutego 2018 r., I OSK 1893/17, LEX nr 2612677.

Wyrok Wojewódzkiego Sądu Administracyjnego w Warszawie z dnia 22 sierpnia 2019 r., VIII SA/Wa 398/19, LEX nr 2769463.

Wyrok Wojewódzkiego Sądu Administracyjnego w Warszawie z dnia 18 września 2019 r., II SA/Wa 1064/19, LEX nr 2865985.

Wyrok Wojewódzkiego Sądu Administracyjnego w Warszawie z dnia 15 listopada 2019 r., II SA/Wa 1432/19, LEX nr 2865521.

Wyrok Wojewódzkiego Sądu Administracyjnego w Warszawie z dnia 24 stycznia 2020 r., II SA/Wa 1491/19, LEX nr 2940150.

\section{LITERATURA}

Kodeks rodzinny i opiekuńczy. Komentarz, red. Henryk Dolecki, Tomasz Sokołowski (Duże komentarze LEX), Wolters Kluwer Polska 2013.

MAŁYSA-SUlińSKA Katarzyna (red.), KAwECKA Anna, SAPETA Joanna: Ustawa o świadczeniach rodzinnych. Komentarz, (Komentarze praktyczne LEX), Wolters Kluwer Polska 2015.

NiTECKI Stanisław, WILK Aleksandra: Ustawa o wspieraniu rodziny i systemie pieczy zastępczej. Komentarz, (Komentarze praktyczne LEX), Wolters Kluwer 2019.

OlsZEWSKI Artur, Ustawa o opiece nad dziećmi w wieku do lat trzech. Komentarz, (Komentarze praktyczne LEX), Wolters Kluwer Polska 2019.

SMYCZYŃSKI Tadeusz: Prawo rodzinne i opiekuńcze, Warszawa: Wydawnictwo C.H. Beck 2016.

TOMASZEWSKA Ewa, Ustawa o pomocy osobom uprawnionym do alimentów. Komentarz, (Komentarze praktyczne LEX), LexisNexis 2014.

Ustawa o pomocy państwa w wychowaniu dzieci. Komentarz, red. Jolanta Blicharz, Jadwiga Glumińska-Pawlic, Lidia Zacharko, LEX/el, Wolters Kluwer 2019.

INNE

Druk nr 3157, www.sejm.gov.pl [dostęp: 01.06.2019]. 


\section{PRZESŁANKI UZYSKANIA \\ RODZICIELSKIEGO ŚWIADCZENIA UZUPEŁNIAJĄCEGO}

Streszczenie

W dniu 1 marca 2019 r. weszła w życie ustawa z dnia 31 stycznia 2019 roku o rodzicielskim świadczeniu uzupełniającym. Jak wskazano w art. 2 ustawy, celem przedmiotowego świadczenia jest zapewnienie niezbędnych środków utrzymania osobom, które zrezygnowały z zatrudnienia lub innej działalności zarobkowej albo ich nie podjęły ze względu na wychowywanie dzieci. W opracowaniu omawiane są przesłanki uzyskania rodzicielskiego świadczenia uzupełniającego. Do wskazanych należą: przesłanka macierzyństwa lub ojcostwa, przesłanka wieku, przesłanka dochodowa, przesłanka ośrodka interesów życiowych. W opracowaniu omawiany jest również problem pozbawienia wolności lub tymczasowego aresztowania osoby otrzymującej rodzicielskie świadczenie uzupełniające.

Słowa kluczowe: rodzicielskie świadczenie uzupełniające; wychowanie; matka; ojciec; dziecko

\section{CONDITIONS FOR OBTAINING THE PARENTAL SUPPLEMENTARY BENEFIT}

\section{S u m m a r y}

On 1 March 2019 the Act of 31 January 2019 on the Parental Supplementary Benefit came into force. As it's indicated in Art. 2 of the Act, the aim of this benefit is providing essential maintenance to persons who resigned from employment or another paid activity, either persons who didn't take employment or another paid activity because of bringing up children. The study describes conditions for obtaining the parental supplementary benefit. Those are: premise of maternity or paternity, requirement of age, criterion of income, term of centre of vital interest. The elaboration analyses also the issue of the parental supplementary benefit's recipient deprivation of liberty or provisional detention.

Key words: parental supplementary benefit; upbringing; mother; father; child 